\title{
PENGEMBANGAN MODEL PELATIHAN SOFT-SKILLS PADA SISWA SEKOLAH MENENGAH PERTAMA NEGERI (SMPN) DI KOTA MATARAM
}

\author{
Anik Darmiany \\ Fakultas Keguruan dan Ilmu Pendidikan-Universitas Mataram-Jl. Majapahit No. 62 Mataram \\ E-mail: anikdarmiany@yahoo.co.id
}

\begin{abstract}
Research and development is aimed to produce soft-skills training models especially in communication skills and emotional control student junior high school (SMP) in Mataram city. Research and development method is carried out through three stages from the ten steps of Borg \& Gall, they are; (1) the preliminary research (needs analysis), (2) the development of training model, (3) Model evaluation and try out. The results show that the development of soft-skills training model develop training manual for counselors and students, as well as soft-skills training materials that meet acceptable criteria of usability, usefulness and feasibility. Besides, the results showed also that there is a difference in scores between pre-test and post-test in skills at managing emotions from unskilled to be very skilled, and communication skills from unskilled become quite skilled.
\end{abstract}

Keywords: development model; soft-skills; junior high school students

\begin{abstract}
Abstrak: Penelitian dan pengembangan ini bertujuan menghasilkan model pelatihan soft-skills khususnya keterampilan komunikasi dan kendali emosi siswa sekolah menengah pertama negeri (SMPN) di kota Mataram. Metode penelitian dan pengembangan dilakukan melalui tiga tahap dari sepuluh langkah Borg \& Gall yaitu, (1) penelitian awal (analisis kebutuhan), (2) pengembangan model pelatihan, (3) uji coba dan evaluasi model. Hasil penelitian menunjukkan bahwa pengembangan model pelatihan soft-skills menghasilkan pedoman pelatihan untuk konselor dan siswa, serta materi pelatihan soft-skills yang memenuhi kriteria keberterimaan dari kegunaan, kemanfaatan, dan kelayakan. Disamping itu hasil penelitian menunjukkan pula bahwa terdapat perbedaan skor antara pre-test dan post-test keterampilan mengelola emosi dari tidak terampil menjadi sangat terampil, dan keterampilan komunikasi dari tidak terampil menjadi cukup terampil.
\end{abstract}

Kata Kunci: pengembangan model; soft-skills; siswa SMP

Secara umum, siswa sekolah menengah pertama berada pada fase remaja kisaran usia 12-16 tahun yang merupakan transisi dari fase kanak-kanak akhir menuju remaja. Masa remaja penuh dengan gejolak emosi sehingga muncul perasaan yang kuat sebagai akibat dari perubahan fisik dan kelenjar. Masa transisi ini ditandai dengan perubahan secara biologis, peranan sex, dan status sosial budaya. Masa goncangan ditandai dengan konflik dan perubahan suasana hati (Hall dalam Santrock, 2003:11). Terhadap kondisi ini masyarakat mengharapkan remaja memenuhi tanggung jawab orang dewasa, padahal di sisi lain perkembangan fisik yang pesat yang tidak diiringi dengan perkembangan psikis yang matang, akan menyebabkan terjadinya "gap" yang cukup lebar. Keadaan ini dapat menyebabkan remaja tidak mampu mengelola emosinya dengan baik sehingga menjadi penyebab munculnya emosi negatif seperti marah, benci, dendam dan lain-lain yang 
dapat menimbulkan konflik batin pada remaja yang berdampak pada terpicunya perilaku agresif (Hurlock, 1999:86).

Sebagaimana yang kita ketahui bahwa kemampuan mengendalikan emosi dan kemampuan berkomunikasi adalah hal yang penting ketika individu sudah menginjak masa remaja. Hal ini disebabkan pada masa remaja individu sudah memasuki dunia pergaulan yang lebih luas, pengaruh teman-teman dan lingkungan sosial akan sangat menentukan. Kegagalan remaja dalam mengelola emosi akan menyebabkan remaja sulit menyesuaikan diri dengan lingkungan sekitarnya sehingga dapat menyebabkan rasa rendah diri, dikucilkan dari pergaulan, cenderung berperilaku yang kurang normatif, dan bahkan dalam perkembangan yang lebih ekstrim bisa menyebabkan terjadinya gangguan jiwa, kenakalan remaja, tindakan kriminal, sampai tindakan kekerasan. Lebih jauh Agustian (2006) menjelaskan bahwa remaja cenderung memandang kehidupan diri dan orang lain hanya menurut apa yang mereka inginkan bukan sebagaimana adanya, terlebih dalam cita-cita. Semakin tidak realistis cita-cita yang dimiliki, menyebabkan semakin meningginya emosi seperti marah yang tak terkendali memicu perilaku agresif yang merupakan ciri dari remaja seperti perkelahian, kekerasan verbal (mencaci maki) maupun kekerasan fisik (memukul, meninju).

Bertolak dari kondisi tersebut, lembaga pendidikan dalam penelitian ini adalah sekolah menengah pertama melalui program bimbingan dan konseling, sangat perlu membentengi para siswa/remaja dengan memberikan pelatihan soft-skills pada siswa-siswa khususnya keterampilan mengelola emosi dan komunikasi. Hal ini penting mengingat bahwa secara umum kondisi remaja yang rentan mengalami kegalauan emosi yang terwujud dalam berbagai rasa emosi negatif, jika tidak diimbangi dengan keterampilan mengelola emosi, mengakibatkan kerugian baik bagi remaja sendiri maupun orang tua dan masyarakat, serta bangsa. Softskills adalah kemampuan untuk bekerja sama dengan orang lain yang memiliki latar belakang berbeda, kemampuan berkomunikasi secara efektif, dan kemampuan dalam mengatasi permasalahan (Goleman, 2006).

Di dalam soft-skills terkandung kemampuan interpersonal yang dibutuhkan masyarakat, dan dunia kerja dimasa mendatang (Linden dalam Syahniar, 2006:3). Kemampuan interpersonal adalah kemampuan untuk berinteraksi dengan orang lain dalam konteks sosial dengan cara yang spesifik dapat diterima oleh masyarakat dan bermanfaat bagi diri serta lingkungan. Berkaitan dengan kemampuan ini, bank dunia memperkenalkan istilah soft-skills yang di dalamnya terkandung kemampuan berkomunikasi dan kendali emosi, yang dibutuhkan masyarakat dan dunia kerja di masa mendatang (Dikbud, 2008). Sejalan dengan itu, Elfindri, dkk (2011:155) menyatakan bahwa kemampuan utama soft-skills adalah komunikasi disamping dua dari tiga komponen utama soft-skills yang sangat dibutuhkan oleh setiap orang agar berhasil dalam kehidupan dan pekerjaan.

Hal ini senanda dengan hasil penelitian yang dilakukan Sprafkin, Greshaw, dkk 1993, yang menyatakan bahwa kurangnya keterampilan menguasai emosi, terutama emosi negatif seperti marah, sedih, frustasi, dan kurangnya keterampilan mengendalikan diri menimbulkan perilaku-perilaku agresif, perilaku-perilaku delinkuen di kalangan remaja

Untuk mengatasi hal tersebut, individu membutuhkan pelatihan soft-skills khususnya keterampilan mengelola emosi, kemampuan untuk mengungkapkan suatu pernyataan, pikiran, perasaan, dan jujur tanpa mengakibatkan perasaan tegang, bersalah maupun cemas (Galassi dan Galassi dalam Hersen, Eisther dan Miller, 1978). Hasil penelitian Conger (1991), menemukan bahwa individu yang memiliki keterampilan mengelola emosi dan mampu berkomunikasi dengan baik cenderung diterima oleh lingkungannya, bebas untuk mengekspresikan dirinya dan merasa puas dalam kehidupannya. Bahkan temuan Elfindri, dkk (2011:10) menjelaskan bahwa soft-skills merupakan kunci untuk meraih sukses. Soft-skills dalam penelitian ini difokuskan pada dua keterampilan yaitu keterampilan mengelola emosi dan komunikasi, dimana kedua keterampilan tersebut tidaklah terbentuk dengan sendirinya melainkan dapat dilatih melalui latihan yang sistematis. Seseorang dapat mempelajari dirinya sendiri dan orang lain serta memahami bagaimana hubungan antar pribadi dapat dibentuk. Soft-skills menunjang keberhasilan dalam bergaul dengan orang lain. Memiliki softskills juga merupakan syarat tercapainya penyesuaian sosial yang baik dalam kehidupan individu.

Secara konseptual, hasil penelitian terdahulu pada tiga sekolah menengah pertama negeri (SMPN) di Mataram menunjukkan bahwa siswa pada tiga SMP tersebut memiliki soft-skills yang rendah, khususnya pada dua keterampilan yaitu mengendalikan emosi dan komunikasi. Permasalahan emosi yang sering dialami remaja selalu dihubungkan dengan masa transisi yang mereka alami dari masa kanak-kanak ke masa dewasa. 
Masa transisi ini ditandai dengan perubahan secara biologis, peranan sex, dan status sosial budaya (Rogers dalam Wahyuni, 2005). Perkembangan fisik yang sangat cepat, menyebabkan fisik mereka hampir menyamai orang dewasa, merupakan salah salah satu pemicu tidak terkendali emosi.

Disamping pelatihan kendali emosi pelatihan komunikasi juga menjadi penting bagi siswa. Memiliki keterampilan dalam berkomunikasi dapat membantu siswa meningkatkan penyesuaian sosial, kerena di dalam komunikasi yang efektif terkandung empati. Empati dijelaskan oleh Milton J. Bennet dalam Mappiare. A, (2013) sebagai "kaidah emas" dan "strategi komunikasi paling tepat ". Alasan inilah yang memicu kebutuhan untuk melatihkan soft-skills khususnya keterampilan mengendali emosi dan komunikasi bagi remaja dengan strategi pelatihan yang mudah dipahami dan dapat diterapkan oleh remaja dalam kehidupan sehari-hari.

Berdasarkan latar belakang tersebut, tujuan dalam penelitian ini dapat dikemukakan sebagai berikut: (1) untuk mengetahui apakah materi pelatihan yang dikembangkan oleh peneliti dapat digunakan oleh konselor untuk melatih soft-skills siswa dan (2) untuk mengetahui efektifitas strategi pelatihan soft-skills yang dikembangkan bila diterapkan pada siswa.

\section{METODE}

Metode penelitian dan pengembangan yang digunakan adalah Research \& Development oleh Borg \& Gall (Depdiknas, 2008). Prosedur penelitian dan pengembangan melalui tiga tahap dari sepuluh langkah Borg \& Gall (1983) yaitu: (1) penelitian awal (analisis kebutuhan), (2) pengembangan model pelatihan, (3) uji coba dan evaluasi model.

\section{Penelitian Awal (Analisis Kebutuhan)}

Penelitian awal dilaksanakan di tiga sekolah menengah pertama negeri yang mewakili SMPN di Nusa Tenggara Barat. Sekolah yang pertama adalah SMPN 14 Sandubaya yang merupakan sekolah paling ujung di kota Mataram, sekolah yang kedua adalah SMPN 1 Mataram yang terletak di tengah kota, dan sekolah yang terakhir adalah SMPN 2 Lobar yang terletak di perbatasan Lombok Barat dan kota Mataram. Ketiga sekolah tersebut dipilih dengan menggunakan teknik random area sampling dengan memilih sekolah yang terletak di ujung barat, timur dan tengah di kota Mataram. Penelitian ini menggunakan angket yang diisi oleh siswa 240 kelas VII sebagai sampel penelitian dari ketiga SMP tersebut. Data yang diperoleh melalui angket tersebut dianalisis menggunakan teknik deskriptif-presentatif. Berdasarkan hasil penelitian awal dikembangkan produk berupa: (1) gambaran jenis soft-skills yang akan dilatihkan, (2) gambaran strategi pelatihan, (3) materi pelatihan yang akan dilaksanakan pada sekolah yang memiliki masalah soft-skills, dan berdasarkan hasil penelitian awal teridentifiasi bahwa SMPN 14 Sandubaya merupakan sekolah yang dipilih sebagai tempat pelatihan soft-skills karena berdasarkan penelitian awal, siswa di sekolah tersebut soft-skillsnya paling rendah dibandingkan dengan kedua sekolah lainnya. Produk tersebut sebelum digunakan terlebih dahulu divalidasi oleh tim ahli rancangan dan isi.

\section{Pengembangan Model}

Tahap kedua menyusun draf pengembangan model pelatihan soft-skills yang terdiri, pedoman pelatihan untuk konselor, pedoman pelatihan untuk siswa, dan materi pelatihan. Pedoman pelatihan tersebut terdiri dari tujuan umum dan khusus, strategi yang digunakan dan langkah-langkah penggunaannya.

\section{Uji Coba dan Evaluasi Model}

Pengembangan tahap ketiga terdiri dari 3 tahap, ahli, konselor dan siswa adalah validasi produk awal oleh ahli (pakar Bimbingan dan Konseling dan Manajemen Pendidikan), yang memiliki pengalaman dalam penelitian pengembangan Bimbingan Konseling. Instrumen yang digunakan untuk melakukan validasi adalah angket tertutup dan terbuka dilampiri naskah produk. Validasi diakhiri dengan diskusi peneliti dan ahli untuk klarifikasi hal-hal penting yang direvisi. Validasi selesai dalam dua putaran, karena telah direvisi sesuai masukan ahli. Naskah produk hasil validasi ahli selanjutnya diujicoba untuk digunakan dalam skala kecil oleh calon pengguna produk. 
Uji coba pengguna produk skala kecil pertama dilakukan oleh 2 orang konselor senior di SMPN 14 Sandubaya. Terdapat dua kegiatan utama dalam ujicoba lapangan skala kecil ini yaitu; (1) melakukan penilaian terhadap kualitas model pelatihan dari aspek kegunaan, kelayakan dan ketepatan dengan tingkat pemahaman pengguna, (2) melakukan penilaian apakah secara keseluruhan model pelatihan memiliki karakteristik yang diharapkan sehingga dapat digunakan oleh calon pengguna (konselor) di sekolah. Instrumen yang digunakan untuk mengukur tingkat soft-skills adalah angket tertutup dan terbuka. Peserta pelatihan (siswa) mengisi angket dua kali yaitu sebelum pelatihan dan setelah pelatihan keberhasilan.

Uji coba pengguna produk skala kecil kedua dilakukan oleh 14 orang siswa kelas VII SMN 14 Sandubaya Kota Mataram berdasarkan kriteria tertentu yaitu siswa yang teridentifikasi kurang mampu bergaul, kurang bisa menyesuaikan diri, sering menyendiri, dan mudah tersinggung. Desain uji lapangan terbatas (siswa) menggunakan desain quasi eksperimen dalam kategori one-group pre-test post-test design. Instrumen yang digunakan untuk mengukur tingkat soft-skills siswa adalah angket tertutup dan terbuka. Peserta pelatihan (siswa) mengisi angket dua kali yaitu sebelum pelatihan (pre-test) dan setelah pelatihan (post-test). Data yang terkumpul dari peserta pelatihan (siswa) dianalisis menggunakan teknik uji-t dengan memanfaatkan aplikasi statistik SPSS 16.0 for windows Release 16.0.0. Pengukuran dilakukan terhadap perubahan teknik pelatihan soft-skills dalam dua keterampilan (kelola emosi, dan komunikasi), sebelum (dianggap sebagai kelompok pertama) dan setelah (sebagai kelompok kedua) mengikuti latihan (Djarwanto, 2008).

Sebagai treatment atau upaya untuk mengatasi permasalahan di SMP 14 Sandubaya, peneliti menggunakan teknik pelatihan dalam pengembangan model pelatihan soft-skill ini mengembangkan salah satu model pembelajaran structured learning approach. Structured learning approach (SLA) dipilih sebagai teknik pelatihan dengan pertimbangan SLA memiliki kriteria seperti yang dikemukakan oleh Munch dan Postleth White (dalam Handarini 2000), bahwa ada hubungan struktural antara komponen-komponen yang digunakan untuk memprediksi konsekuensi-konsekuensi dan dapat diverifikasi melalui observasi, serta dapat memperjelas peristiwa belajar, dalam rangka mengembangkan konsep-konsep baru. Faktor penting lainnya dalam teknik ini mengandung unsur affektif (feeling), kognitif (thinking), dan psikomotorik (doing). Unsur-unsur tersebut akan membentuk pemahaman yang integral dalam diri peserta latihan terhadap materimateri yang dilatihkan.

Materi-materi pelatihan soft-skills dalam penelitian berkaitan dengan pengendalian emosi dan komunikasi merupakan materi yang bertujuan untuk mengembangkan keterampilan baik kognitif, afektif, maupun perilaku. Maka pemilihan model pembelajaran yang mencakup ketiga aspek tersebut merupakan bagian yang penting dalam menentukan sebuah teknik pelatihan efektif atau tidak. Tujuan akhir dari pelatihan soft-skills ini adalah agar siswa memiliki keterampilan transfer of learning, sehingga diharapkan mereka dapat mentransfer keterampilan pengendalian emosi dan komunikasi ke situasi di luar pelatihan atau dalam kehidupan sehari-hari. Keterampilan transfer of learning atau keterampilan individu mengontrol pengetahuan yang diperoleh untuk diaplikasikan dalam masalah baru. Menurut Gagne (dalam Santrock 2013: 237), individu yang memiliki keterampilan ini, dikatakan memiliki strategi kognitif yaitu kemampuan internal seseorang yang terorganisasi dapat membantu siswa dalam proses belajar, proses berpikir, memecahkan masalah dan mengambil keputusan. Proses pembelajaran dengan menggunakan strategi kognitif merupakan proses reflection in action, yang terkandung dalam SLA.

Empat teknik intervensi SLA digunakan dalam pelatihan yaitu: modelling, role playing, feedback, transfer of training (Sprafkin, et all., 1993), dalam pelatihan soft-skill ini dikembangkan sebuah komponen lagi, yaitu istruksi. Menurut Smith \& Sandhu (2004), bahwa intervensi dengan teknik SLA disebut pendekatan positivis, cara mengajar individu melalui kolaborasi lima teknik dengan intervensi ketika pelatihan dilaksanakan.

\section{Pemberian Model (Modelling)}

Model dilakukan oleh peneliti disertai dengan pemberian materi latihan yang dipraktekkan langsung dalam kelompok. Siswa belajar melalui pengamatan dan tingkah laku baru diperoleh atau ditingkatkan setelah melihat orang lain mendemonstrasikan tingkah laku yang diharapkan. 


\section{Permainan Peran (Role Playing)}

Pada tahap ini siswa diminta untuk memerankan tingkah laku yang dimodelkan oleh peneliti dalam bentuk permainan. Jenis permainan peran yang digunakan dalam penelitian ini adalah sosiodrama. Tujuan utama permainan dalam penelitian ini adalah menunjukkan pada orang lain bagaimana seseorang harus berperilaku. Sementara pemain sendiri dapat mempelajari perilaku yang diperankan serta berusaha memperbaiki atau meniru perilaku yang sebenarnya diharapkan.

\section{Umpan Balik (Feedback)}

Feedback merupakan informasi balikan dari suatu sumber yang berguna untuk mengatur tingkah laku (Chaplin, 1999). Dalam pemberian feedback, penting sekali diingat bahwa komentar-komentar harus mengacu pada kehadiran atau kekurangan yang khusus, tingkah laku-tingkah laku konkret, dan seharusnya tidak mengambil bentuk dari komentar-komentar penilaian umum atau generalisasi luas (Goldstein, Gershaw, dan Sprafkin, 1985).

\section{Transfer of Training (Pemberian Tugas Rumah)}

Pemberian tugas rumah adalah alat yang paling umum untuk mengefektifkan transfer keterampilanketerampilan yang baru dipelajari (Sprafkin, Gershaw, Goldstein, 1993). Dengan menggunakan pemberian tugas rumah, anggota-anggota kelompok diinstruksikan secara eksplisit untuk berlatih keterampilan yang telah dimainperankan dalam kelompok ke dalam situasi nyata di luar kelompok (Sprafkin, Gershaw, Goldstein, 1993). Peserta diminta untuk membuat catatan dalam usahanya mentransfer keterampilan dalam format laporan tugas rumah yang disediakan oleh pelatih. Goldstein, Sprafkin, Gershaw, dan Klein (1980) menjelaskan sebagai berikut: format ini meminta informasi detail tentang apa yang terjadi saat peserta berusaha melaksanakan kewajiban tugas rumah, bagaimana baiknya ia mengikuti langkah-langkah tingkah laku relevan, evaluasi peserta dari penampilannya, dan apa yang ia pikirkan tentang apa kemungkinan kewajiban yang akan datang dilakukan.

\section{Instruksi}

Instruksi adalah penjelasan verbal tentang apa yang dimaksud dengan soft-skills, mengapa soft-skills perlu dilatihkan, serta bagaimana soft-skills siswa yang dikehendaki, baik secara verbal maupun non verbal. Rosenshine (dalam Rothstein, 1990) mendefinisikan instruksi sebagai "structured approach where students are made aware of goals, instruction is comprehensive, performance is monitored, and feedback is given". Dalam penelitian ini instruksi digunakan dalam setiap tahap pelatihan untuk memperjelas hal-hal atau cara para peserta pelatihan melakukan keterampilan yang dilatihkan. Disamping itu instruksi merupakan cara mengarahkan siswa peserta pelatihan untuk memahami kompenen soft-skills tidak saja terkait kemampuan berkomunikasi dengan situasi yang dikehendaki, namun juga bagaimana soft-skills /keterampilan komunikasi dan kendali emosi dalam merespon orang lain yang tidak sependapat dengan kita, serta apa makna softskills tersebut dalam suatu situasi tertentu.

\section{HASIL DAN PEMBAHASAN}

Hasil penelitian ini didasarkan pada tiga tahapan model Borg dan Gall (1983) yaitu (1) penelitian awal (analisis kebutuhan), (2) pengembangan model pelatihan, dan (3) uji coba dan evaluasi model. Tahap pertama yakni penelitian awal, tahap ini merupakan upaya melakukan analisis kebutuhan terhadap perlu tidaknya pelatihan dilakukan. Hasil yang diperoleh dari sebaran angket pada 240 siswa di tiga sekolah SMPN di kota Mataram adalah: (1) siswa pada tiga sekolah menengah pertama (SMP) tersebut soft-skillsnya yang meliputi kendali emosi dan komunikasi sangat perlu dilatih dan dikembangkan; (2) konselor atau guru bimbingan dan konseling di sekolah sangat membutuhkan strategi pelatihan soft-skills; (3) pelatihan dilaksanakan pada sekolah yang memiliki masalah soft-skills. Dari analisis tersebut, teridentifikasi bahwa SMPN 14 Sandubaya sebagai tempat pelatihan soft-skills. 
Tahap kedua yakni pengembangan model pelatihan. Draf awal pedoman pelatihan soft-skills dinilai oleh dua ahli. Ini merupakan langkah pengembangan untuk mengetahui akseptabilitas produk (berguna, tepat, dan layak). Hasil penilaian ahli menunjukkan bahwa pelatihan soft-skill khususnya keterampilan kendali emosi dan komunikasi dengan teknik pelatihan structured learning approach memenuhi kriteria dan layak diadaptasi sebagai teknik pelatihan soft-skills bagi siswa sekolah menengah pertama (SMP). Kedua orang ahli memberikan penilaian tinggi pada ketiga aspek. Artinya substansi dari strategi structured learning approach yang dikembangkan tersebut sudah akseptabel. Aspek kegunaan pedoman secara kumulutif tingkat skor rata-rata yang diberikan oleh kedua ahli mencapai total skor sebesar 74 berarti sangat berguna, aspek kelayakan total skornya sebesar 53 artinya termasuk dalam kriteria sangat layak, aspek ketepatan total skornya 63,5 artinya termasuk dalam kriteria tepat. Demikian pula dengan aspek ketepatan rumusan tujuan dan langkah-langkah menggunakan teknik pelatihan, kedua ahli mengatakan bahwa modul yang digunakan sebagai pedoman pembelajaran tepat diterapkan untuk siswa Sekolah Menengah Pertama. Menurut Dick dan Carey (1990), bahwa pedoman merupakan arah mengenai cara pelaksanaan semua komponen yang ada dalam pelatihan, karena di dalamnya tercantum rumusan pengetahuan, keterampilan, dan sikap yang akan dicapai.

Berdasarkan hasil analisis uji ahli dapat disimpulkan bahwa secara umum pedoman pelatihan softskills yang dikembangkan dalam penelitian ini cukup memadai untuk dijadikan sebagai pedoman konselor dalam pelatihan soft-skills siswa di sekolah. Produk awal (draf pengembangan pedoman pelatihan softskills) yang terdiri, pedoman pelatihan untuk konselor, pedoman pelatihan untuk siswa, dan perangkat materi pelatihan yang dikembangkan oleh peneliti dan telah divalidasi oleh dua orang ahli, dinilai memiliki tingkat kegunaan, ketepatan, dan kelayakan yang "tinggi".

Tahap ketiga yakni uji coba dan evalusi model. Pada tahap ini, dilakukan validasi oleh pakar. Hasil penilaian tahap pertama (uji ahli), dilakukan beberapa penyempurnaan sesuai masukan dan saran ahli, kemudian dilanjutkan dengan uji coba pada kelompok calon pengguna terbatas konselor. Data yang diperoleh dari penilaian tahap kedua ada tiga macam yaitu: (a) penilaian calon pengguna (konselor), saat pelatihan dan setelah pelatihan dilaksanakan dan (b) hasil skor yang dicapai peserta pelatihan berdasarkan pre-test dan post-test. Uji lapangan skala kecil konselor (terbatas) menunjukkan hasil yang senada bahkan lebih tinggi dari ahli bahwa: pedoman pelatihan untuk konselor, dan siswa, serta perangkat materi pelatihan yang dikembangkan oleh peneliti memiliki tingkat kegunaan, ketepatan, dan kelayakan "sangat tinggi". Komponenkomponen yang berkaitan dengan kegiatan latihan yang dikembangkan dalam structured learning approach, berdasarkan penilaian calon pengguna (konselor) juga memenuhi kriteria sangat berguna, layak, tepat. Komponen ini meliputi: (1) petunjuk umum dan petunjuk khusus, (2) langkah-langkah pelatihan, (3) contohcontoh yang diberikan, dan (4) tugas rumah secara keseluruhan komponen tersebut jelas dan mudah dilaksanakan oleh konselor. Pernyataan konselor ini merupakan cermin dari suatu kegiatan pelatihan yang aplikatif tidak hanya teori. Contoh dalam pelatihan model yang digunakan ini adalah live model (model hidup), peneliti sendiri yang berperan sebagai model, dengan menampilkan secara langsung keterampilan, perilaku, emosi yang diharapkan sebagai contoh bagi peserta pelatihan. Peserta secara sukarela diminta untuk mengulang perilaku yang dicontohkan di depan kelas, dengan teknik bermain peran. Peserta memerankan kelompok sebaya yang perilaku sosialnya dapat ditiru oleh peserta lain, yang dapat juga dijadikan model nyata.

Sementara itu, hasil uji-t pre-test dan post-test kelompok terbatas siswa menunjukkan bahwa terdapat perbedaan signifikan soft-skills siswa dalam keterampilan kendali emosi, dan keterampilan komunikasi antara sebelum dan setelah pelatihan soft-skills diberikan. Perubahan tingkat kendali emosi cukup tinggi mencapai $75 \%$, dan kemampuan berkomunikasi 63\%. Perubahan yang terjadi setelah pelatihan menunjukkan pada dua jenis keterampilan cukup tinggi, dapat dijelaskan bahwa dua keterampilan tersebut sangat dibutuhkan dan menjadi kebanggaan bagi siswa bila dapat mengendalikan emosi terutama emosi negatif, serta memiliki kemampuan berkomunikasi dengan baik di depan umum merupakan suatu kebanggaan pada remaja. Hal ini sesuai dengan penjelasan Kendall (2005), bahwa pelatihan soft-skills (pengendalian diri, dan komunikasi) dapat membantu siswa remaja untuk (1) menyadari peranan pikiran dapat memunculkan emosi, (2) mengendalikan pikiran-pikiran tersebut untuk mengatasi emosi-emosi yang mengganggu, (3) belajar bagaimana pengaruhnya terhadap perilaku, dan (4) memiliki keterampilan untuk mengkomunikasi hal-hal yang dirasakan untuk mengendalikan atau mengubah perilaku. 
Soft-skills (keterampilan kendali emosi dan komunikasi) pada dasarnya dapat dipelajari dan dilatihkan kepada setiap orang, melalui pelatihan yang intensif, khususnya melalui program pelatihan di sekolah (Hallahan \& Kauffman, 1998). Penelitian ini membuktikan bahwa model pelatihan soft-skills khususnya keterampilan kendali emosi dan komunikasi menggunakan structured learning approach terbukti efektif dalam mengembangkan soft-skills siswa sekolah menengah pertama negeri di kota Mataram.

\section{SIMPULAN DAN SARAN}

\section{Simpulan}

Berdasarkan uraian hasil kajian di atas dapat disimpulkan: (1) pelatihan soft-skill bagi siswa SMP terdiri atas tiga jenis produk yaitu: (a) pedoman pelatihan untuk konselor, (b) pedoman pelatihan untuk siswa, (c) materi pelatihan; (2) pedoman pelatihan yang dihasilkan telah melewati tahap uji ahli, uji kelompok kecil calon pengguna produk (konselor), dan uji kelompok terbatas (siswa); (3) materi pelatihan tergolong pada kualifikasi sangat berguna, layak dan tepat, setelah pelatihan menunjukkan bahwa structured learning approach efektif untuk melatih soft-skills siswa, khususnya pada dua jenis keterampilan yaitu, kendali emosi dan komunikasi.

Kesimpulan yang bisa ditarik dari penelitian dan pengembangan ini adalah pengembangan modul dilaksanakan melalui tahap uji coba. Hasil dari kegiatan pengembangan tersebut yaitu:

Pertama, pedoman pelatihan yang dikembangkan telah memiliki komponen-komponen yang dapat menunjang terlaksanaannya kegiatan latihan soft-skills siswa di SMPN Mataram. Komponen-komponennya meliputi: (a) panduan untuk konselor dan siswa (b) materi pelatihan soft-skills terdiri atas dua topik yaitu: (a) keterampilan kendali emosi, dan (b) keterampilan komunikasi, menunjukkan hasil penilaian akseptabilitas menunjukan bahwa materi yang digunakan dalam pelatihan tergolong pada kualifikasi sangat berguna berdasarkan penilaian ahli.

Kedua, komponen-komponen yang berkaitan dengan kegiatan latihan yang dikembangkan dalam pelatihan, berdasarkan penilaian calon pengguna (konselor) juga memenuhi kriteria sangat berguna, layak dan tepat. Komponen ini meliputi: (a) petunjuk umum dan petujuk khusus, (b) langkah-langkah pelatihan (c) contohcontoh yang diberikan dan (d) tugas rumah secara keseluruhan komponen-komponen tersebut tergolong pada kualifikasi akseptabel.

Ketiga, proses kegiatan dan hasil latihan yang dicapai oleh siswa peserta latihan tergolong pada kualifikasi akseptabel, berdasarkan skor pre-test dan post-test untuk dua jenis keterampilan dalam pelaksanaan pelatihan terlihat setelah dilaksanakan menunjukan bahwa peserta memperoleh peningkatan keterampilan secara meyakinkan, tergolong dalam kategori sangat terampil. Perubahan tingkat keterampilan tersebut yang tertinggi terjadi pada jenis "keterampilan kendali emosi" (75\%) dan "keterampilan komunikasi" (63\%), pada "keterampilan kendali emosi" mengalami peningkatan, ini menunjukkan jenis keterampilan tersebut sangat dibutuhkan dan menjadi kebanggaan bagi siswa bila dapat mengendalikan emosi terutama emosi negatif dalam diskusi kelompok secara terampil.

Berdasarkan hal-hal yang telah dikemukakan di atas, secara umum dapat dikatakan bahwa pelaksanaan pelatihan ini berhasil sehingga perlu untuk terus dikembangkan atau dilaksanakan oleh konselor di Sekolah.

\section{Saran}

Saran pemanfaatan modul: (1) agar mencapai hasil optimal konselor sebagai pengguna produk agar memiliki kompetensi teknis, keterampilan komunikasi dan kendali emosi, serta menguasai teknik-teknik pelatihan, (2) konselor perlu diberikan pelatihan singkat tentang teknik SLA, (3) dalam pelaksanan pelatihan konselor harus menyiasati waktu, tidak dilaksanakan pada jam formal, tetapi dilakukan pada jam ekstrakurikuler.

Saran untuk penelitian lanjutan: (1) hasil penelitian menunjukkan bahwa structured learning approach dapat meningkatkan soft-skills siswa (khususnya pada empat jenis keterampilan komunikasi dan kendali emosi). Hal ini baru diamati/diketahui selama pelatihan berlangsung, belum dilakukan pengamatan di luar setting pelatihan. Sehingga perlu dilakukan penelitian lanjutan untuk mengetahui apakah soft-skills yang 
telah dilatihkan dapat dipertahankan, (2) teknik structured learning approach perlu dikembangkan pada jenis soft-skills yang berbeda untuk mengetahui keefektifan yang lebih sempurna, (3) penelitian ini hanya pada tahap melaksanakan tahap revisi produk akhir, belum sampai pada tahap implementasi sehingga belum dapat digunakan di luar penelitian ini. Oleh sebab itu, masih perlu ditindaklanjuti sampai pada tahap akhir.

\section{DAFTAR PUSTAKA}

Agustian, H. 2006. Psikologi Perkembangan: Pendekatan Ekologi Kaitannya dengan Konsep Diri dan Penyesuaian Diri Pada Remaja. Bandung: Rafika.

Borg, W. R. \& Gall, M. D. 1983. Educational Research: An Introduction. London: Longman, Inc.

Frijda, N. H. 2005. Emotion Experience. Cognition and Emotion, 19, 473-497.

Goleman, D. 2002. Keserdasan Emosi untuk Mencapai Puncak Prestasi. (terjemahan). Jakarta: PT Gramedia.

Dany, M. H. 2000. Pengembangan Model Pelatihan Keterampilan Sosial bagi SMU Terpadu., Disertasi, tidak diterbitkan. Malang: Program Pascasarjana. Universitas Negeri Malang.

Depdiknas. 2008. Metode Penelitian Pengembangan. Pusat Penelitian Kebijakan dan Inovasi Pendidikan. Jakarta: Badan Penelitian dan Pengembangan Departemen Pendidikan Nasional

Djarwanto, 2008. Statistik Nonparametrik. Yogyakarta: BPFE-Yogtakarta.

Elfindri, dkk, 2011. Soft-skills untuk Pendidik. Praninta Offset.

Gardner, H. 1993. Multiple Intelligence. New York: Basic Book.

Goleman, D. 1999. Emosional Intelligence. Jakarta: PT. Gramedia Pustaka Utama.

Hurlock, E. B. 1995. Psikologi Perkembangan. Alih Bahasa: Sijabat. M. R. Erlangga: Jakarta.

Johnson, D.W. dan Frank, P. J. 1991. Joining Together Group Theory and Group Skill. 4 th.ed. Prentice Hall inc. New Jersey.

Kaipa P \& Milus T. 2005. Soft-skills are Smart Skills. Diunduh dari http://www.kaipagroup.com.

Kaufman, M. J., Gottlieb, J., Agard, J. A. \& Kukic, M.A. 1975. Mainstreaming: Toward An Explication of The Construct. Focus on Exceptional Children, 1-15.

Kendal, P. C., Mychailyzyn, M. P, Mendez J. L. (2010). School Functioning in Youth With And Without Anxiety Disorders: Comparison by Diagnosis and Comorbidity. School Psychology Review Vol 39, No 1, PP 106-121.

Mappiare, A-T. A., 2010. Kontrak Belajar Bernilai Sosial Budaya dalam PA. Jurnal Pendidikan dan Pembelajaran, Vol 17, No 1 April.

Santrock W. 2014. Psikologi Pendidikan. Jakarta, Salemba Hunika.

Syahniar, 2006. Pengelolaan Program Pembelajaran Ditinjau dari Peningkatan Interpersonal Siswa. Disertasi, tidak diterbitkan. Malang: Program Pascasarjana. Universitas Negeri Malang. 